\title{
Department of Homeland Security Websites Uncoupled: An Evaluation of Online Counterterrorism and Security Information across Agencies
}

\author{
Anna L. Langhorne \\ University of Dayton, Department of Communication \\ 300 College Park, Dayton, Ohio 45469-1410 \\ Alanghorne1@udayton. edu
}

\begin{abstract}
The purpose of this paper is to describe the content focus and hyperlink structure of the Department of Homeland Security (DHS) websites. This exploratory research is the first phase of a long-term effort to assess the degree to which information provided by DHS websites reflects the communication and information requirements of U.S. citizens. The present study uses content analysis and web link analysis methodologies to examine nine primary DHS websites. The findings reveal there are differences among the primary DHS agency websites in the use of hyperlinks and the coverage of national security topics.
\end{abstract}

Keywords: Department of Homeland Security, national security, content analysis, hyperlink analysis, information sharing, usability, communication, cyber security.

\section{Introduction}

With heightened concerns about terrorism, the current national security landscape requires that U.S. Federal agencies communicate efficiently, effectively, and accurately with agency stakeholders. Consequently, the World Wide Web (WWW) is one of many mediums available for facilitating government-citizen communication. The WWW enables government agencies to provide personalized e-governance services to citizens [1]. Moreover, citizens require information about policies, procedures, and current issues related to counterterrorism and national security in order to assist the government in vigilance and to preserve personal safety. Because ICT has the potential to improve government transparency through relevant and timely information distribution [2], government websites are salient mechanisms for communicating with citizens.

The U.S. government's interest in using the WWW is demonstrated by its estimated 11,013 Federal websites [3]. The Federal government recognizes that successful agency websites have the potential to create "a more citizen centered government" [4]. Furthermore, Federal agencies are required to improve customer service and 
efficiently manage their websites by addressing information dissemination mandates such as information quality, objectivity, utility, and integrity [5].

The purpose of this exploratory study is to determine the nature and extent of terrorism, counterterrorism and national security information presented on the Department of Homeland Security (DHS) websites. The DHS, an agency tasked with preserving the nation's security, safety, and resiliency, has approximately thirty-six Federal websites under its purview. DHS websites are intended to satisfy critical citizen information needs, especially during high-uncertainty situations. However, it is unclear whether 1) DHS-generated website content is designed to meet citizen national security information needs and 2) It conforms to government information usability standards [6].

Past studies have focused on important issues: Cyber warfare and security [7], terrorist network identification [8, 9], agency information sharing [10], interoperability [11], and information assurance [12]. And with regard to U.S. government websites, the literature has focused considerably on usability and accessibility assessments of websites $[13,14,15,16]$.

There is a dearth of literature, however, characterizing the content of government websites. Furthermore, no studies were found that evaluated the DHS website semantic structures from usability, communication, and hyperlink structure perspectives.

In the present study, content analysis, a quantitative method for systematically studying the characteristics of communication content, is applied to a sample of DHS websites. The objectives are: 1) Identify the occurrence frequency of citizen-focused national security information presented via DHS agency websites, 2) Identify information inconsistencies in the web content across DHS websites, and 3) Articulate the hyperlink structure of the DHS websites in reference to each other.

\section{Methodology}

\subsection{Sample}

A sample of nine websites was selected from an estimated population of thirty-six DHS websites (See Table 1). The sample selection was based on the DHS' designation of the following websites as primary: www.dhs.gov, www.fema.gov, www.fletc.gov, ww.ice.gov, www.secretservice.gov, www.tsa.gov, www.uscg.mil, www.uscis.gov, and www.cbp.gov [17]. All nine sampled DHS websites were analyzed for patterns across content themes and the agency-to-agency hyperlink structure within the context of citizen-focus and agency purpose.

\subsection{Content Analysis}

A content-analysis methodology was used to examine the sample of nine primary DHS websites. The data comprised web page content, which incorporated all file formats (e.g., .pdf and .doc), on the primary DHS agencies' websites. The data collection was performed in February 2013. The content was analyzed using a coding 
scheme that was created to classify national security issues from a citizen perspective. The coding scheme centered on four primary categories: Communication, proactive measures, threats/incidents, and post-incident response. Google Advanced Search was used to conduct queries of each website for each national security topic listed in the coding scheme in Table 2.

Table 1. DHS website sample

\begin{tabular}{|c|c|c|c|}
\hline DHS agency & Daily & Abbreviation & Agency purpose \\
\hline $\begin{array}{l}\text { U.S. Department of } \\
\text { Homeland Security }\end{array}$ & www.dhs.gov & DHS & $\begin{array}{l}\text { To ensure U.S. homeland is safe, } \\
\text { secure, and resilient against terror- } \\
\text { ism and other hazards }\end{array}$ \\
\hline $\begin{array}{l}\text { Federal Emergency } \\
\text { Management Agency }\end{array}$ & www.fema.gov & FEMA & $\begin{array}{l}\text { Support U.S. citizens and first } \\
\text { responders to prepare for, protect } \\
\text { against, respond to, recover from, } \\
\text { and mitigate all hazards }\end{array}$ \\
\hline $\begin{array}{l}\text { Federal Law Enforce- } \\
\text { ment Training Center }\end{array}$ & www.fletc.gov & FLETC & $\begin{array}{l}\text { Interagency law enforcement train- } \\
\text { ing for } 91 \text { Federal agencies }\end{array}$ \\
\hline $\begin{array}{l}\text { U.S. Immigration \& } \\
\text { Customs Enforcement }\end{array}$ & www.ice.gov & ICE & $\begin{array}{l}\text { Homeland security and public } \\
\text { safety through criminal and civil } \\
\text { enforcement of border control, } \\
\text { customs, trade, and immigration } \\
\text { laws }\end{array}$ \\
\hline U.S. Secret Service & $\begin{array}{l}\text { www.secretservice. } \\
\text { gov }\end{array}$ & SS & $\begin{array}{l}\text { Protects national and visiting for- } \\
\text { eign leaders, and conducts criminal } \\
\text { investigations }\end{array}$ \\
\hline $\begin{array}{l}\text { Transportation Securi- } \\
\text { ty Administration }\end{array}$ & www.tsa.gov & TSA & $\begin{array}{l}\text { Maintains security of the traveling } \\
\text { public and sets transportation secu- } \\
\text { rity standards }\end{array}$ \\
\hline U.S. Coast Guard & www.uscg.mil & USCG & $\begin{array}{l}\text { Maritime military enforcement } \\
\text { along rivers, ports, littoral regions } \\
\text { and on high seas }\end{array}$ \\
\hline $\begin{array}{l}\text { U.S. Citizenship and } \\
\text { Immigration Services }\end{array}$ & www.uscis.gov & USCIS & $\begin{array}{l}\text { Provide accurate and useful infor- } \\
\text { mation, grant immigration and } \\
\text { citizenship benefits, promote citi- } \\
\text { zenship awareness and understan- } \\
\text { ing, and protect the immigration } \\
\text { system }\end{array}$ \\
\hline $\begin{array}{l}\text { U.S. Customs \& Border } \\
\text { Protection }\end{array}$ & www.cbp.gov & CBP & $\begin{array}{l}\text { Safeguard the U.S. borders and } \\
\text { homeland and protect the Ameri- } \\
\text { can public against terrorism }\end{array}$ \\
\hline
\end{tabular}

\subsection{Web Link Analysis}

Web link analysis is a network analysis method used to articulate the structure among web nodes that associate with each other via hyperlinks. This study applies an approach used to evaluate the web link structure of the web space occupied by the American Library \& Information Science field [18]. Essentially, the hyperlink data between sites are mined and analyzed for directional patterns. 
The data consisted of hyperlinks identified from the primary agencies' websites under the umbrella of the Department of Homeland Security. The in- and out-link data were gathered from the nine websites using Google Advanced Search. Google Advanced Search was designed to collect such hyperlinks to external domains. The data collection was performed in February 2013.

Table 2. DHS coding scheme

\begin{tabular}{|c|c|}
\hline \multicolumn{2}{|c|}{ National security topic categories } \\
\hline \multirow[t]{7}{*}{ Communication } & Emergency procedures \\
\hline & Warning system \\
\hline & Progress reporting \\
\hline & Emergency information \\
\hline & Citizen hotline \\
\hline & Crime reporting \\
\hline & Safety information \\
\hline \multirow[t]{7}{*}{ Readiness } & Action plan \\
\hline & Disaster preparedness \\
\hline & Emergency preparedness \\
\hline & Emergency plan \\
\hline & Emergency kit \\
\hline & Safety plan \\
\hline & Workplace plan \\
\hline \multirow{4}{*}{$\begin{array}{l}\text { Threat/ } \\
\text { incident }\end{array}$} & Pandemic \\
\hline & Fire \\
\hline & Crime victim \\
\hline & $\begin{array}{l}\text { Terrorist weapon types (e.g., chemical, biologi- } \\
\text { cal) }\end{array}$ \\
\hline \multirow[t]{4}{*}{ Post-incident response } & Returning home \\
\hline & Help survivors \\
\hline & Emergency assistance \\
\hline & Casualty \\
\hline
\end{tabular}

\section{Results and Discussion}

The national security topics addressed by the primary DHS websites showed some commonalities. As shown in Table 3, topics of focus across many DHS websites included emergency procedures, emergency information, safety information, emergency preparedness, and emergency assistance. Because DHS agencies are tasked with protecting the nation and its citizens, it follows that considerable web content would relate to emergency communication, readiness, and response. However, many agency websites completely neglected or weakly provided content in numerous categories. 
Table 3. DHS content analysis results

\begin{tabular}{|c|c|c|c|c|c|c|c|c|c|c|}
\hline \multicolumn{2}{|c|}{$\begin{array}{l}\text { National security } \\
\text { topics }\end{array}$} & $\begin{array}{l}\mathrm{DH} \\
\mathrm{S}\end{array}$ & $\begin{array}{l}\text { FEM } \\
\mathrm{A}\end{array}$ & $\begin{array}{l}\text { FLET } \\
\mathrm{C}\end{array}$ & ICE & SS & $\begin{array}{l}\text { TS } \\
\text { A }\end{array}$ & $\begin{array}{l}\text { USC } \\
\text { G }\end{array}$ & $\begin{array}{l}\mathrm{CI} \\
\mathrm{S}\end{array}$ & $\begin{array}{l}\mathrm{CB} \\
\mathrm{P}\end{array}$ \\
\hline \multirow{7}{*}{ 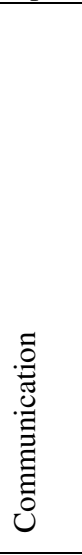 } & $\begin{array}{l}\text { Emergency } \\
\text { procedures }\end{array}$ & $\begin{array}{l}109 \\
0\end{array}$ & 2980 & 330 & 418 & 35 & 479 & 2390 & 0 & 389 \\
\hline & $\begin{array}{l}\text { Warning } \\
\text { sys }\end{array}$ & 568 & 20300 & 61 & 251 & 16 & 239 & 955 & 0 & 310 \\
\hline & $\begin{array}{l}\text { Progress } \\
\text { report }\end{array}$ & 975 & 2010 & 25 & 236 & $\begin{array}{l}95 \\
1\end{array}$ & 108 & 1220 & 0 & 279 \\
\hline & $\begin{array}{l}\text { Emergency } \\
\text { informa- } \\
\text { tion }\end{array}$ & $\begin{array}{l}342 \\
0\end{array}$ & 56400 & 514 & 977 & 61 & $\begin{array}{l}143 \\
0\end{array}$ & 6220 & 0 & $\begin{array}{l}251 \\
0\end{array}$ \\
\hline & $\begin{array}{l}\text { Citizen } \\
\text { hotline }\end{array}$ & 114 & 329 & 2 & 97 & 10 & 6 & 68 & 0 & 94 \\
\hline & $\begin{array}{l}\text { Crime } \\
\text { reporting }\end{array}$ & 815 & 283 & 24 & 500 & 52 & 33 & 402 & 0 & 170 \\
\hline & Safety info & $\begin{array}{l}212 \\
0\end{array}$ & 21400 & 751 & $\begin{array}{l}251 \\
0\end{array}$ & 79 & 667 & 6920 & 0 & $\begin{array}{l}196 \\
0\end{array}$ \\
\hline \multirow{7}{*}{ 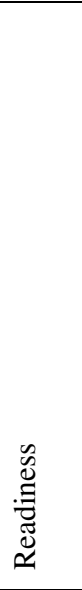 } & $\begin{array}{l}\text { Action } \\
\text { plan }\end{array}$ & $\begin{array}{l}171 \\
0\end{array}$ & 3940 & 56 & 424 & 44 & 278 & 3320 & 0 & 577 \\
\hline & $\begin{array}{l}\text { Disaster } \\
\text { prepared- } \\
\text { ness }\end{array}$ & 942 & 2180 & 5 & 20 & 2 & 39 & 416 & 0 & 19 \\
\hline & $\begin{array}{l}\text { Emergency } \\
\text { prepared- } \\
\text { ness }\end{array}$ & $\begin{array}{l}130 \\
0\end{array}$ & 38700 & 277 & 38 & 14 & 102 & 752 & 0 & 45 \\
\hline & $\begin{array}{l}\text { Emergency } \\
\text { plan }\end{array}$ & $\begin{array}{l}249 \\
0\end{array}$ & 83000 & 325 & 506 & 43 & 359 & 4300 & 0 & 544 \\
\hline & $\begin{array}{l}\text { Emergency } \\
\text { kit }\end{array}$ & 140 & 19800 & 5 & 238 & 0 & 69 & 341 & 0 & 72 \\
\hline & Safety plan & $\begin{array}{l}138 \\
0\end{array}$ & 2030 & 458 & 851 & 59 & 231 & 3410 & 0 & 410 \\
\hline & $\begin{array}{l}\text { Workplace } \\
\text { plan }\end{array}$ & 388 & 2030 & 20 & 94 & 20 & 78 & 812 & 0 & 108 \\
\hline \multirow[b]{4}{*}{ 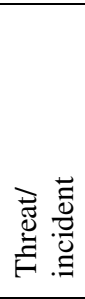 } & Pandemic & 339 & 533 & 0 & 7 & 1 & 6 & 11 & 0 & 9 \\
\hline & Fire & $\begin{array}{l}144 \\
0\end{array}$ & $\begin{array}{l}14000 \\
0\end{array}$ & 255 & 562 & 33 & 74 & 6360 & 0 & 930 \\
\hline & $\begin{array}{l}\text { Crime } \\
\text { victim }\end{array}$ & 334 & 89 & 95 & 250 & 35 & 8 & 191 & 0 & 49 \\
\hline & $\begin{array}{l}\text { Terrorist } \\
\text { weapon } \\
\text { types }\end{array}$ & $\begin{array}{l}152 \\
0\end{array}$ & 1560 & 0 & 1 & 0 & 3 & 5 & 0 & 0 \\
\hline \multirow{4}{*}{ 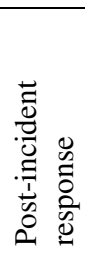 } & $\begin{array}{l}\text { Returning } \\
\text { home }\end{array}$ & 210 & 906 & 32 & 247 & 6 & 33 & 739 & 0 & 305 \\
\hline & $\begin{array}{l}\text { Help sur- } \\
\text { vivors }\end{array}$ & 238 & 10200 & 0 & 13 & 2 & 7 & 855 & 0 & 18 \\
\hline & $\begin{array}{l}\text { Emergency } \\
\text { assistance }\end{array}$ & $\begin{array}{l}117 \\
0\end{array}$ & 28700 & 146 & 361 & 34 & 171 & 1960 & 0 & 493 \\
\hline & Casualty & 157 & 1460 & 1 & 11 & 2 & 3 & 2970 & 0 & 64 \\
\hline
\end{tabular}


Primary examples are the U.S. Secret Service (SS) and the U.S. Citizenship and Immigration Services (CIS). The SS exhibited minimal content in every category, except progress report. Although this may mirror its reputation for covertness, it fails to comport with the Federal government's conception of an open digital government. Similarly, the CIS website failed to exhibit content in every category. The complete absence of information is a concern especially for new citizens or those in the process of becoming citizens, who may lack knowledge about other government agency websites. Notable content deficits existed for TSA in the areas of citizen hotline, crime reporting, and terrorist weapon types. Again, when considered within the context of a citizen focus, many agencies failed to empower citizens; DHS websites frequently exhibited gaps in relevant information.

In addition to the differences found in DHS website content, there was variance among the DHS website hyperlinks. Given the Federal directive to improve information sharing, it is interesting to note the vast differences in hyperlinking among the primary DHS websites (See Table 4). The DHS website accounts for $48.64 \%$ of the links to www.dhs.gov from other primary DHS websites and $26.56 \%$ of the links to primary DHS websites. Because DHS is the parent agency for the other primary DHS agencies, it follows that DHS would possess the greatest number of in- and out-links. Contrastingly, www.fletc.gov, the website of a training facility/school, exhibited marginal in- and out-links accounting for less than $1 \%$ in both cases. Because FLETC's relevance to the general public is limited, the low hyper linkage to other DHS websites is not a concern. The remaining agencies, however, may improve citizen service by increasing linkages to related content at relevant agency websites. It is anticipated that strategic hyperlinking will facilitate information sharing among citizens.

Table 4. Descriptive statistics of Department of Homeland Security websites' in- and out-link asymmetric matrix data

\begin{tabular}{|l|l|l|l|l|l|l|}
\hline \multirow{2}{*}{$\begin{array}{l}\text { Organization } \\
\text { website }\end{array}$} & \multicolumn{2}{l|}{$\begin{array}{l}\text { (A) In-links from other } \\
\text { DHS sites }\end{array}$} & \multicolumn{2}{l|}{$\begin{array}{l}\text { (B) Out-links to other } \\
\text { DHS sites }\end{array}$} & \multicolumn{2}{l|}{ (C) Total (A + B) } \\
\cline { 2 - 7 } & Frequency & Ratio & Frequency & Ratio & Frequency & Ratio \\
\hline DHS & 1412 & $48.64 \%$ & 771 & $26.56 \%$ & 2183 & $37.6 \%$ \\
\hline FEMA & 382 & $13.16 \%$ & 686 & $23.63 \%$ & 1068 & $18.39 \%$ \\
\hline FLETC & 24 & $.83 \%$ & 6 & $.2 \%$ & 30 & $.52 \%$ \\
\hline ICE & 231 & $7.96 \%$ & 113 & $3.89 \%$ & 344 & $5.9 \%$ \\
\hline SS & 28 & $.97 \%$ & 10 & $.34 \%$ & 38 & $.65 \%$ \\
\hline TSA & 257 & $8.85 \%$ & 128 & $4.41 \%$ & 385 & $6.63 \%$ \\
\hline USCG & 131 & $4.51 \%$ & 303 & $10.44 \%$ & 434 & $7.48 \%$ \\
\hline CIS & 249 & $8.58 \%$ & 765 & $26.35 \%$ & 1014 & $17.46 \%$ \\
\hline CBP & 189 & $6.51 \%$ & 121 & $4.17 \%$ & 310 & $5.34 \%$ \\
\hline TOTAL & 2903 & & 2903 & & 5806 & \\
\hline
\end{tabular}




\section{$4 \quad$ Future Research and Limitations}

This study provided an initial assessment of the content subject matter of primary DHS websites and the agency-to-agency hyperlink structure. The magnitude of the DHS websites presented a feasibility issue. It was difficult, if not impossible, to assess with certainty all of the citizen-focused website content. In future project stages, the researcher will address this issue and will code the content after sorting by file format (e.g., .pdf, .ps, .dwf, .kml, .kmz, .xls, .ppt, .doc, .rtf, and .swf). In the present study, the site architecture and sheer volume of website pages demanded reliance on automated search tools. Although such tools were effective, some error was likely produced due to a tool's inability to capture the qualitative dimension of information. Furthermore, it was beyond the scope of the current project to confirm whether or not the content location and type as citizen-focused were consistent. Future research will investigate this issue. Additionally, it would be informative to evaluate the primary agency-to-agency hyperlink structure within the context of citizen-focused topic areas to determine whether interagency connections appropriately support citizen-focused communication of information. Finally, a questionnaire will be developed 1) to identify salient topics which remain absent from the DHS websites and 2) to assess citizen perceptions of the utility of the information.

\section{Conclusion}

This study analyzed the semantic structure of national security information presented via DHS agency websites, identified information patterns in the web content, and described the hyperlink structure of agency-to-agency directed links. Based on the results of the aforementioned analyses, the national security topics addressed by the primary DHS websites shared commonalities in the content themes, but also fundamental differences. Furthermore, as indicated by the preliminary results of the hyperlink analysis, a refocusing of the content and structure toward citizen users may be warranted to achieve improved information sharing with the public.

\section{References}

1. Pieterson, W., Ebbers, W., van Dijk, J.: Personalization in the Public Sector: An Inventory of Organizational and User Obstacles Towards Personalization of Electronic Services in the Public Sector. Government Information Quarterly 24(1), 148-164 (2007)

2. Kim, P., Halligan, J., Cho, N., Oh, C., Eikenberry, A.: Toward Participatory and Transparent Governance: Report on the Sixth Global Forum on Reinventing Government. Public Administration Review 65(6), 646-654 (2005)

3. Gov Reform Task Force. State of the Federal Web Report (Report), 60 (December 16, 2011) (retrieved January 3, 2012)

4. Johnson, C.: Policies for Federal Agency Public Websites. M-05-04 Memorandum for the Heads of Executive Departments and Agencies (December 17, 2004) 
5. Gordon, D., Kundra, V.: Improving the Accessibility of Government Information. Memorandum for Chief Acquisition Officers, Chief Information Officers (July 19, 2010)

6. Executive Order 13571; OMB Circular A-130

7. Ahmad, R., Yunos, Z., Sahib, S.: Understanding Cyber Terrorism: The Grounded Theory Method Applied. In: 2012 International Conference on IEEE Cyber Security, Cyber Warfare and Digital Forensic (CyberSec), pp. 323-328 (2012)

8. Sageman, M.: Understanding Terror Networks. University of Pennsylvania Press (2011)

9. Perliger, A., Pedahzur, A.: Social Network Analysis in the Study of Terrorism and Political Violence. PS: Political Science and Politics 44(1), 45 (2011)

10. Relyea, H.: Homeland Security and Information Sharing: Federal Policy considerations. Government Information Quarterly 21(4), 420-438 (2004)

11. Headayetullah, M., Pradhan, G.: Interoperability, Trust Based Information Sharing Protocol And Security: Digital Government Key Issues. International Journal of Computer Science \& Information Technology 2(3), 72-91 (2010)

12. Bellomo, S., Woody, C.: DoD Information Assurance and Agile: Challenges and Recommendations Gathered Through Interviews with Agile Program Managers and DoD Accreditation Reviewers. Software Engineering Institute (2012)

13. Youngblood, N., Mackiewicz, J.: A Usability Analysis of Municipal Government Website Home Pages In Alabama, Government Information Quarterly (2012)

14. Baker, D.: Advancing e-government performance in the United States through enhanced usability benchmarks. Government Information Quarterly 26(1), 82-88 (2009)

15. West, D.M.: State and Federal Electronic Government in the United States. The Brookings Institution, Washington, DC (2008)

16. Olalere, A., Lazar, J.: Accessibility of U.S. Federal Government Home Pages: Section 508 Compliance and Site Accessibility Statements. Government Information Quarterly 28(3), 303-309 (2011)

17. http: //www. dhs.gov/dhs-website-directory

18. Joo, S.: A Web Link Structure of the American Library \& Information Science Field: A Pilot Study (2010) 